\title{
Model Analysis of Check Dam Impacts on Long-Term Sediment and Water Budgets in Southeast Arizona, USA
}

KEYWORDS: Soil and Water Assessment Tool (SWAT), calibration, conservation, check dams, aridlands

\begin{abstract}
The objective of this study was to evaluate the effect of check dam infrastructure on soil and water conservation at the catchment scale using the Soil and Water Assessment Tool (SWAT). This paired watershed study includes a watershed treated with over 2000 check dams and a Control watershed which has none, in the West Turkey Creek watershed, Southeast Arizona, USA. SWAT was calibrated for streamflow using discharge documented during the summer of 2013 at the Control site. Model results depict the necessity to eliminate lateral flow from SWAT models of aridland environments, the urgency to standardize geospatial soils data, and the care for which modelers must document altering parameters when presenting findings. Performance was assessed using the percent bias (PBIAS), with values of $+/-2.34 \%$. The calibrated model was then used to examine the impacts of check dams at the Treated watershed. Approximately 630 tons of sediment was stored behind check dams in the Treated watershed over the 3-year simulation, which increases the water quality to an acceptable level for fish habitat there. A minimum precipitation event of $15 \mathrm{~mm}$ was found necessary to instigate the detachment of soil, sediments, or rock from the study area, which occurred $2 \%$ of the time. The resulting watershed model is useful as a predictive framework and decision-support tool to consider long-term impacts of restoration and potential for future restoration.
\end{abstract}

\subsection{Introduction}

Soil erosion by water is one of the most important land degradation processes in aridland environments and is linked to flooding and water-resource management (Poesen and Hooke 1997). Sediment transport in streams is a major nonpoint source pollutant (NPS) in surface waters that compromises water clarity and health by increasing water temperatures and decreasing dissolved oxygen (Branson et al. 1981; Gray et al. 2000). Sediment can also serve as a transport mechanism for other pollutants. Rockström et al. (2010) argue that investments in catchment-scale management of water and soils is necessary to minimize the risk for climaterelated failures and emphasize water harvesting systems to build resilience and address trade-offs between ecosystem services. Studies of rock structures placed in channels document the decrease in peak flows (Baker et al. 1995; Peterson et al. 1960; Norman et al. 2010a; 2010b; 2015), reduction in sediment load (Hadley and McQueen 1961; Hassanli et al. 2008: Polyakov et al. 2014), and increased vegetation (Bombino et al. 2009; Debano and Heede 1987; Debano and Schmidt 1990; Heede 1978; Heede and DeBano 1984; Hendrickson and Minckley 1985; Norman et al. 2014).

Kingsford (2001) suggests better models of ecological and hydrological impacts of dam installation for an improved understanding of the interaction between river flows, floodplain ecology, and management practices. Traditional models cannot consider all the watershed-scale erosion and sediment transport processes at once due to knowledge and/or data limitations (De Vente and Poesen 2005). However, there are many models that have been applied to develop estimates of runoff, erosion, and sediment yield and to mimic how check dams and rock structures might influence those (Martín-Rosales et al. 2007; Remaître et al. 2008; Boix-Fayos et 
al. 2008; Norman et al. 2010a; 2010b; Garbrecht et al. 2014). In this study, we simulate the hydrologic processes documented in riparian areas treated with check dams using the Soil and Water Assessment Tool (SWAT; Arnold et al. 1998; Neitsch et al. 2009) to extend the hydrologic budget and describe the fate and transport of sediments. In selecting a model to use, our goals were to extrapolate on our limited field data, be sparing with the adjustment of parameters, provide better estimates of the response, and contribute to the scientific understanding of the impacts of check dams in aridlands.

In valleys of these arid and semiarid rangelands, fluvial sediment deposits accumulate on low parts of hillslopes or in the channel and floodplains (Osterkamp 1999; Coblentz 2005). Gullies are formed by flowing water eroding soil on a hillside and leads to the destruction of riparian habitat in headwater channels (Debano and Schmidt 1990). Material is easily carried along when runoff begins on a hillslope but this declines after the first flush, as new sediment must be detached (Zabaleta et al. 2007). Rates of sediment delivery in aridlands are hard to document due to the ephemeral nature of local streams and large flood-recurrence intervals (Griffiths et al. 2006). The U.S. Department of Agriculture - Agricultural Research Service (USDA-ARS) Southwest Watershed Research Center (SWRC) is monitoring water and soil at two heavilyinstrumented locations in the Madrean Sky Islands: the Walnut Gulch Experimental Watershed (WGEW) and the Santa Rita Experimental Range (SRER). WGEW is a $149 \mathrm{~km}^{2}$ research area, approximately $312 \mathrm{~mm}$ of precipitation is measured annually and elevation ranges $730 \mathrm{~m}(1220$ 1950m; Goodrich et al. 2008). Nearing et al. (2007) found that few precipitation events produce sediment yields, ranging 0.07-5.7 t/ha/yr, on watersheds $<5$ ha and Nichols (2006) reported 0.17-1.1 t/ha/yr on larger (35-159ha) watersheds. Schreiber and Kincaid (1967) documented runoff to be most dependent on storm size vs. antecedent moisture. The SRER in a $210 \mathrm{~km}^{2}$ study site where $250-500 \mathrm{~mm}$ of precipitation is measured annually and elevation ranges 500m (9001400m; Polyakov et al. 2010). Lane et al. (1997) found rainfall extent and intensity, vegetative, soil cover, and topography influence sediment yield. Polyakov et al. (2010) document approximately $6.4 \%$ of rainfall events produce runoff, with the primary driver being the intensity - sediment yield occurs in $26 \%$ of runoff events $(0.85-6.69 \mathrm{t} / \mathrm{ha}$ yr).

Negative effects of accelerated erosion and sedimentation on water quality have been welldocumented in the Madrean Sky Islands (Lopes and Ffolliott 1992; Marsh 1968) and in other environments (Gray et al. 2000; Marsh 1968; and Zabaleta et al. 2007). Soil and water conservation experts have developed Best Management Practices (BMPs) to reduce soil loss and improve water quality (Young et al. 2010). Check dams and rock gabions are examples of BMPs that can help to stabilize channels and trap sediment in upstream deposits. These deposits provide a nutrient-rich foundation that helps instigate plant establishment and promotes growth (Debano and Schmidt 1990). By trapping sediment, these features also help improve water quality downstream, through attenuation of particles and pollutants (Pettersson 1998). Griffiths and Walton (1978) suggest 80-100 milligrams of solids per liter $(\mathrm{mg} / \mathrm{L})$ is the upper tolerance level for fish.

It is difficult to discern if changes in fluvial-sediment load is the result of changes in management (BMPs, grazing, etc.), climate, or if they are part of natural cycles triggered when a geomorphic threshold is exceeded (Osterkamp 1999). The objective of this research is to provide a predictive framework to analyze impacts of restoration in a three-year model iteration which 
could be projected into the future and to guide the further restoration of ecological processes. The installation of check dams is assessed in the context of demonstrating the benefit of these features for protecting water quality. We hypothesize that the installation of a series of check dams can support storage of organic soils and carbon, improve water quality, and increase local water supplies. Our primary results include annual estimates of runoff, evapotranspiration, soilwater storage, soil erosion, and watershed sediment yield at a paired watershed site.

\subsection{Materials and Methods}

\subsection{Study Area}

In the mid-western slope of the Chiricahua Mountains, in Southeast Arizona, average annual precipitation is $534 \mathrm{~mm}$, with approximately $70 \%$ occurring July through September (Fuller 2015). A historic stream gage (1919-1925) documented average annual daily flow at West Turkey Creek $\sim 0.24$ cubic meters per second (cms), which nearly doubled during the monsoon (US Geological Survey 2015). This a valuable perennial stream and the largest source of water contributing to both the Willcox Playa and groundwater Basin (Fig. 1), but lowering water levels (Brown and Schumann 1969; Jacobson et al. 2008) and total dissolved solids impact drinking water (Arizona Department of Water Resources 2009).

Proprietors at El Coronado Ranch, who lease the West Turkey Creek allotment from the U.S. Forest Service, began installing low-lying rock check dams in 1983 averaging > 2.5 check dams per ha. Now, more than 2000 loose-rock structures have been strategically constructed by hand and placed in tributaries flowing into the Turkey Pen sub-watershed (769 ha). The Turkey Pen is approximately $5 \mathrm{~km}$ long, with 554-meter change in elevation. Sands, silts, and clays with organic material have deposited and filled areas above the dams, forming wide areas of alluvial deposits. Norman et al. (2015) paired the adjacent and untreated (Control) Rock Creek watershed (2405 ha) to document variations in discharge using a modified-Continuous Slope Area method. The Rock Creek flows through deep channels, with large boulders, and over exposed bedrock and is approximately $10 \mathrm{~km}$ from outlet to peak, where topographic relief varies by $1238 \mathrm{~m}$. Results demonstrated a lower runoff response (peak flow) in the Turkey Pen (Treated) watershed, yet $28 \%$ more volume via extended base-flows. 


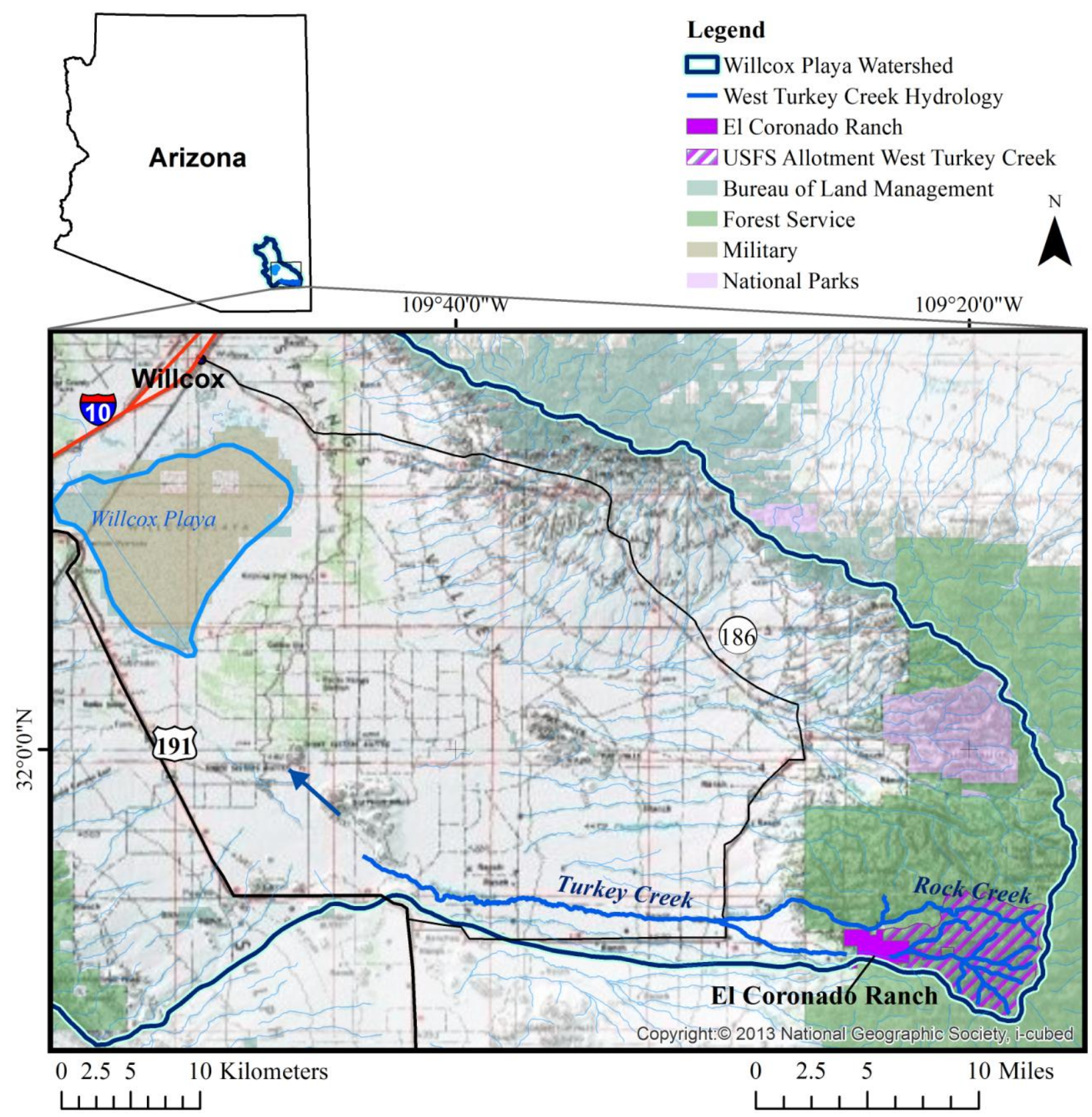

Figure 1. Map portraying the location of the West Turkey Creek hydrology in relationship to the Willcox, Playa, City of Willcox, Willcox Playa Watershed, and the State of Arizona.

Photographs from the intersection of Turkey Pen (Treated) to West Turkey Creek (Figures 2a and 2b), and of the gages situated at Rock Creek (Control; Figure 2c) and Turkey Pen (Treated; Figure 2d) during high flows, demonstrate reduced turbidity in treated channels, but waterquality hasn't been documented. 


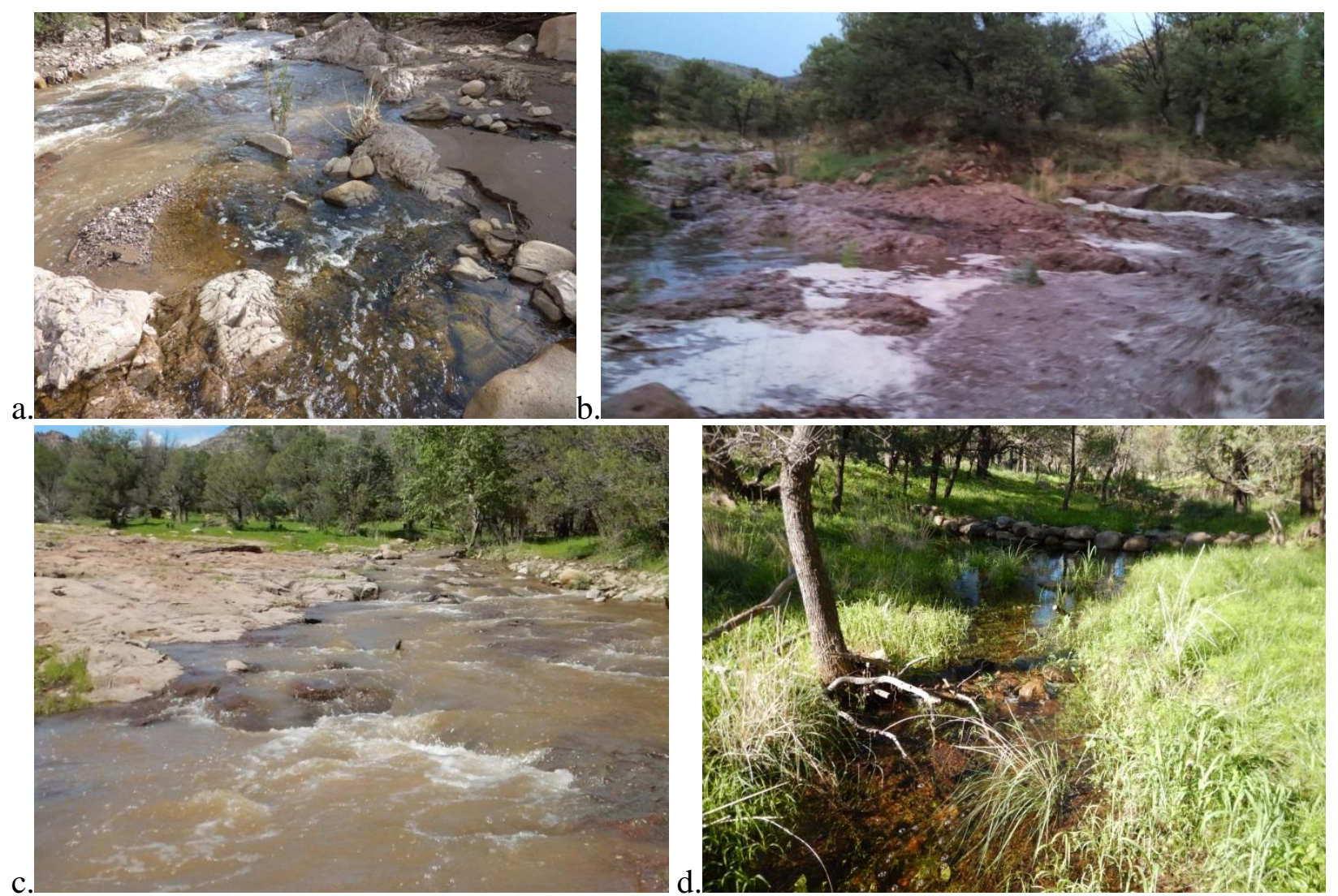

Figure 2: Photographs display clarity of the Turkey Pen (Treated) vs. turbity at the confluence with West Turkey Creek (untreated) a.) looking downstream and Turkey Pen (Treated) on right (8/30/13; E. Gwilliam); b.) looking upstream where Turkey Pen (Treated) coming in on the left side (8/28/14; L. Norman). Photographs of gages during high flow at c.) Rock Creek (Control; 8/14/14) and d.) Turkey Pen (Treated; 8/5/14; by F. Brinkerhoff).

\subsection{Model presentation and calibration}

\subsubsection{Model Characteristics}

The Soil and Water Assessment Tool (SWAT), developed by USDA-ARS and Texas A\&M University, is a physically-based, continuous time, watershed-modeling program that can predict yields of water, sediment, nutrients, and agricultural chemicals in large watersheds (Arnold et al. 1998; Neitsch et al. 2009). It is a public domain hydrological-transport model that can operate on a daily-time step in basin scale. SWAT calculates surface runoff and accommodates for some transmission losses. Water that infiltrates the surface is divided into multiple layers for routing, and some moves through the soil via 'lateral flow' or unsaturated flow. The combination of surface runoff, lateral flow, and return flow contributes to the streamflow being estimated. A detailed description of SWAT can be found in Neitsch et al. (2009). Calibration is suggested to improve model performance and increase the reliability of flow predictions. Niraula et al. (2012a; 2015) found that it is important to calibrate the model spatially to analyze the effect of land-use change but not as important for climate change impacts. 
SWAT calculates erosion based on the Universal Soil Loss Equation (USLE; Eq. 1), which estimates average annual soil loss at the plot scale (Wischmeier and Smith 1978):

Equation 1. USLE: $\mathbf{A}=\mathbf{R} * \mathbf{K} * \mathrm{LS} * \mathbf{C} * \mathbf{P}$

where, $\mathrm{A}=$ predicted soil loss (tons/acre/year), $\mathrm{R}=$ rainfall and runoff factor, $\mathrm{K}=$ soil erodibility factor, $\mathrm{LS}=$ slope factor (length and steepness), $\mathrm{C}=$ crop and cover management factor, and $\mathrm{P}=$ conservation/support practice factor. The amount of sediment to reach the channel can be calculated using a sediment delivery ratio (SDR) multiplied by estimates of gross erosion (Williams 1977). Many modifications of the USLE, some with geospatially derived SDR's have been used to quantify sediment loads in SE Arizona (Brady et al. 2001; Norman 2005, 2007,Norman et al. 2007). SWAT substitutes a SDR by using a derived runoff factor instead of the rainfall factor (Bonumá et al. 2014) and applies the modified-USLE (MUSLE) to simulate estimates of sediment yield (Williams 1975; Eq. 2).

Equation 2. $\mathrm{Y}=11.8 *\left(\mathrm{Q}_{\text {surf }} * \mathrm{q}\right.$ peak $*$ area $\left._{\mathrm{HRU}}\right){ }^{0.56} * \mathrm{~K} * \mathrm{LS} * \mathrm{C} * \mathrm{P} * \mathrm{CRFG}$ where $\mathrm{Y}$ is the sediment yield (metric tons/day), $\mathrm{Q}_{\text {surf }}$ is the surface runoff volume $\left(\mathrm{mm} \mathrm{H}_{2} \mathrm{O} / \mathrm{ha}\right)$, $\mathrm{q}_{\text {peak }}$ is the peak runoff rate $\left(\mathrm{m}^{3} / \mathrm{s}\right)$, area $\mathrm{HRU}_{\text {is }}$ is the area of the HRU (ha)], and CFRG is the coarse fragment factor $[\mathrm{CFRG}=\exp (-0.053 *$ rock $)$, where rock is the percent rock in the first soil layer $(\%)$ ]. All factors are determined by SWAT from the input data or during the each model run (Q and q), except for P, which defaults to 1. SWAT then estimates sediment using both lateral and groundwater sources (Chaubey et al. 2006). Sediment yield is simulated for each unique hydrological response unit, independent of relational landscape position within each subwatershed (White 2001; White et al. 2010).

SWAT is based on mechanisms derived from plot-scale studies which present challenges for mimicking BMPs and scaling processes up to the watershed level (Arnold et al. 1998; Gassman et al. 2007). SWAT has various surface-water impoundment tools (potholes, wetlands, ponds, and reservoirs) to simulate the impacts on hydrology and sediment and/or nutrients (Du et al. 2005) and these have been modified by many scientists in different applications (Arnold et al. 2001; Almendinger et al. 2014; Kiesel et al. 2010; Liu et al. 2008; Mishra et al. 2003; 2007; Ouessar et al. 2008; Tesfahunegn et al. 2013; Waidler et al. 2011; Wang et al. 2008; 2010; Wang and Lu 2012). Yang et al. (2009) used SWAT to assess the flow diversion terrace impacts on surface water quality in the Black Brook Watershed, New Brunswick, Canada. Results indicated flow diversion terraces contributed to the reduction of sediment yield by $56 \%$, and reduced water yield during the summer growing seasons by $20 \%$. In the Yanhe watershed $\left(7725 \mathrm{~km}^{2}\right)$, Loess Plateau, China, 6572 check dams ( 1 check dam/118 ha) have been installed beginning in 1970's. Xu et al. (2013) split data into rainy/dry seasons to account for monsoons in SWAT, finding that in rainy seasons (May - October) runoff decreased by 16-30\% and sediment decreased $\sim 35-86 \%$, and in dry season (November-April), runoff increased by 20-101\%. Mwangi et al. (2015) used SWAT to evaluate multiple conservation practices in the Sasumua Watershed, Kenya $\left(107 \mathrm{~km}^{2}\right)$, including filter strips, contour farming, parallel terraces, grassed waterways, and their combinations finding various reductions in surface runoff and sediment yields along with slight increases in base flow.

\subsubsection{Data Used in this Study for Model Calibration}

An effort was made to document the location of all the check dams in the main channels the Turkey Pen (Treated) watershed using a handheld Garmin global positioning system (GPS) receiver (Figure 3), but we still observe many more tucked into each little drainage and along 
every hillslope. In fact, the density of check dams has altered the channel characteristics too drastically to portray as surface-water impoundments.

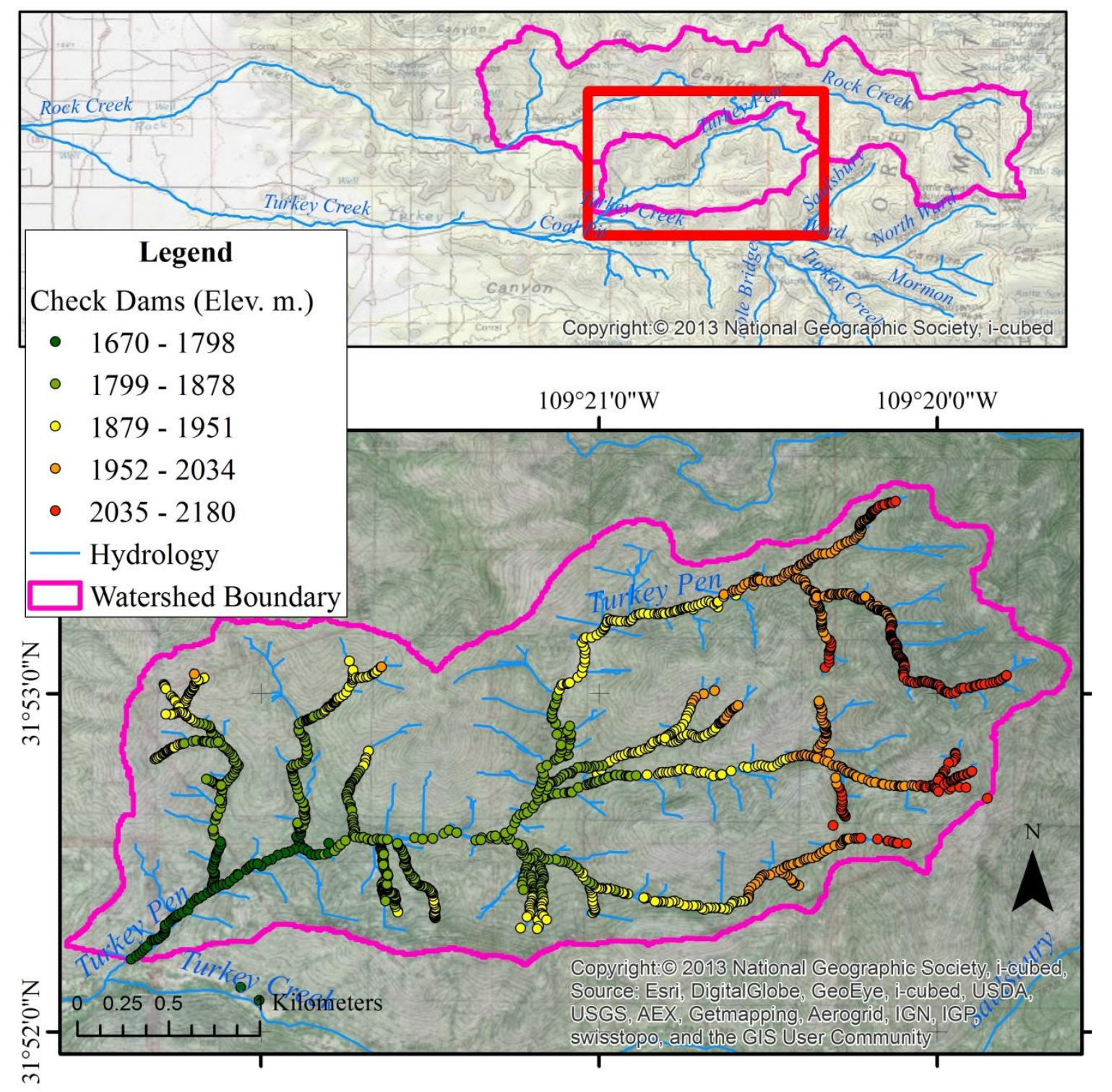

Figure 3. Map portraying hydrology with digitized check dams classified by elevation, in the Turkey Pen Watershed, where the top inset depicts the location in West Turkey Creek.

Discharge data collected by Norman et al. (2015) from June to October, 2013, from the paired watershed hydrographs were used to calibrate the SWAT model. First, we calibrated the SWAT model using the field data collected from the outlet at Rock Creek (Control). Then, the calibrated parameters from the Rock Creek model were transferred to the Turkey Pen model, which allowed for model simulation representing the situation without the check dams. Finally, we compared differences between the observed hydrological and simulated data at Turkey Pen (Treated), to document the influence of check dams on the hydrologic and sediment budgets, on an annual basis. 
Soils, topographic, land-use, and daily weather data were collected from difference sources and assembled in a geodatabase. Geospatial data were clipped to the study area and converted to a common Universal Transverse Mercator (UTM) projection. Soils data were mapped by the USDA Natural Resource Conservation Service (NRCS), collected at scales ranging from $1: 12,000$ to $1: 250,000$, representative of the dominant component in the mapping unit. However, the higher resolution Soil Survey Geographic Database (SSURGO) dataset has poor representation at our study area, because NRCS does not map USFS land at the same scale as private lands. Oddly, the older and generally lower-resolution State Soil Geographic (STATSGO) dataset had better spatial resolution in our study area. Furthermore, polygons describing soil have little to no tabular data and geospatial properties from the STATSGO soil map and the soil database downloaded with ArcSWAT 2009 were manually merged (Winchell et al. 2009). The highest-resolution digital elevation models (DEM) were found at 1/3 arc-second $(\sim 10 \mathrm{~m})$ and downloaded from the National Elevation Dataset (NED). The USGS National Land Cover Database (NLCD2006) is a 16-class land-cover classification based on the Landsat Enhanced Thematic Mapper+ (ETM+) from 2006 at a spatial resolution of 30m (Wickham et al. 2014). Daily precipitation and temperature data for two weather stations located in or at the perimeters of, the combined $\sim 32 \mathrm{~km}^{2}$ study area were assimilated for input to the model. The West Turkey Creek ALERT gage $3040\left(31^{\circ} 51^{\prime} 36.00^{\prime \prime} \mathrm{N}, 109^{\circ} 20^{\prime} 9.00^{\prime \prime W}\right)$ is approximately 0.6 $\mathrm{km}$ south of the edge of the Turkey Pen (Treated) at $1907 \mathrm{~m}$. elevation and the Long Park ALERT gage 3090 (31 $\left.{ }^{\circ} 53^{\prime} 46.30^{\prime \prime} \mathrm{N}, 109^{\circ} 17^{\prime} 0.30 " \mathrm{~W}\right)$ is at the peak of the Rock Creek (Control), elevation $2768 \mathrm{~m}$ (Fuller 2015). These event-based tipping buckets report in real-time whenever there is $1 \mathrm{~mm}$ of precipitation.

There is no observed sediment data for which to calibrate the sediment predictions in the model. However, we know that the magnitude, duration, and frequency of the flows will dictate the behavior of bedload or suspended sediment load (Gray et al. 2000; Marsh 1968; and Zabaleta et al. 2007). Therefore, we relied solely on the calibration of the flow regime. We pushed all sediment parameters and routing variables to their maximum options to test the sensitivity of these to predicted sediment deposition to create a qualitative measure, but sediment yield from the HRU that is transported into the main channel during the time step (SYLD) predictions resulted in negligible changes in every output file. We attribute this to the fact that SYLD is predicted using generated runoff in SWAT (vs. precipitation) and our adjustments to the code minimize lateral flows.

A sediment delivery ratio (SDR) was applied based on drainage area and multiplied by the soil (gross) erosion predicted using the USLE for determining average annual sediment yield. Vanoni (1975) used the data from 300 watersheds throughout the world to develop a generalized equation to estimate SDR (Eq. 4).

Equation 3. SDR $=0.4724 \mathrm{~A}^{0.125}$; where, $\mathrm{A}=$ watershed area $(\mathrm{km} 2)$

The USDA Soil Conservation Service (USDA-SCS 1975) developed an equation to calculate SDR based on the data from the Blackland Prairie, Texas (Eq. 5):

Equation 4. $\mathrm{SDR}=0.51 \mathrm{~A}^{-0.11}$, where $\mathrm{A}=$ drainage area in square miles. While these are not standard SWAT equations, we applied them outside of the model to estimate a watershed SDR and resulting sediment yield. 
SWAT discretized channels and flow paths of the system using a minimum threshold area (25 ha) to define a stream. Eleven points were added to represent tributaries collected using GPS in the field. Two outlets were documented at the confluences of both the paired watersheds (Turkey Pen and Rock Creek) where the tributaries were monitored in the summer of 2013, and 81 subbasins (averaging $0.39 \mathrm{~km} 2$ ) were defined. We used a threshold value of $10 \%$ for land use, soil and slope in defining hydrologic response units (HRUs) s, ultimately generating 666 total HRUs in ArcSWAT Version 2012.10_1.6 (released 2/11/13; Winchell et al. 2009) and was run for 3 years $(8 / 26 / 11-9 / 30 / 14)$.

\subsection{Results and Discussion}

Seasonal discharge for the monsoon season in 2013, developed by Norman et al. (2015), served as the basis of the calibration. First the model was calibrated to accommodate the water balance and then the shape of the hydrograph. At the control site, only $\sim 2 \frac{1}{2} \%$ of precipitation is observed to be allocated to surface runoff in the channel (Norman et al. 2015). Almost all flow in aridlands is surface runoff (vs. subsurface or lateral flow) and we adopted a customized script for the modeling in the Santa Cruz Watershed (developed by Niraula et al. 2015), to account for the very-low flow in the unsaturated zone due to rainfall. A rigorous manual calibration approach was adopted to further refine the SWAT model for the study area based on a review of current literature that identified parameters commonly adjusted (Arnold et al. 2001). Prior knowledge from past studies in the region was also relied upon for possible parameter ranges and the most sensitive parameters (Niraula 2012a; 2015). After the model results mimicked the observed water budget, the calibration was focused to match the rainfall-runoff response to storms, time lags, and travel times and imitate the shape of the observed data's hydrograph in terms of peaks, recession, and antecedent moisture conditions. An informal sensitivity analysis was carried out by varying parameters one at a time to create a qualitative measure of parameter sensitivities (Niraula et al. 2012b). The final calibration consisted of adjusting only the coefficients listed in Table 1.

Table 1. SWAT model parameters included in the calibration and final adjustment.

\begin{tabular}{|l|l|l|c|c|c|}
\hline Parameter & Description & File & Default & Range & $\begin{array}{l}\text { Calibrated } \\
\text { value }\end{array}$ \\
\hline ESCO & $\begin{array}{l}\text { Soil evaporation compensation } \\
\text { factor }\end{array}$ &. bsn & 0.95 & $0-1$ & 0.1 \\
\hline TRNSRCH & $\begin{array}{l}\text { Fraction of transmission losses } \\
\text { from main channel that enter } \\
\text { deep aquifer }\end{array}$ & .bsn & 0 & $0-1$ & 0.36 \\
\hline REVAPMN & $\begin{array}{l}\text { Threshold depth of water in } \\
\text { shallow aquifer }\end{array}$ &.$g w$ & 1 & $0-500$ & 0 \\
\hline GW_DELAY & Ground water delay time, days &.$g w$ & 31 & $0-500$ & 15 \\
\hline CN2 & $\begin{array}{l}\text { Initial Soil Conservation Service } \\
\text { runcurve number for moisture } \\
\text { condition II }\end{array}$ & .mgt & varies & $35-82$ & X 0.75 \\
\hline CH_K(2) & $\begin{array}{l}\text { Effective hydraulic conductivity } \\
\text { in main channel alluvium } \\
\text { (mm/hr) }\end{array}$ & .rte & 0 & $\begin{array}{c}0.01- \\
500\end{array}$ & 10 \\
\hline
\end{tabular}




\begin{tabular}{|l|l|l|c|c|c|} 
SOL_AWC & $\begin{array}{l}\text { Available water capacity of the } \\
\text { soil }\end{array}$ & .sol & $0-1$ & $0-1$ & X 1.5 \\
\hline USLE_K & $\begin{array}{l}\text { USLE equation soil erodibility } \\
\text { K) factor }\end{array}$ & .sol & varies & $0-0.65$ & 0.25 \\
\hline USLE_C & $\begin{array}{l}\text { USLE C factor for water erosion } \\
\text { applicable to the land cover/plant }\end{array}$ & plant.dat & 0.003 & $\begin{array}{c}0.001- \\
0.5\end{array}$ & 0.25 \\
\hline
\end{tabular}

Hyetohydrographs portray average precipitation $(\mathrm{mm})$ in relationship to both observed and the modeled discharge (cms) at Rock Creek (Control; Fig. 4), and Turkey Pen (Treated; Fig. 5).

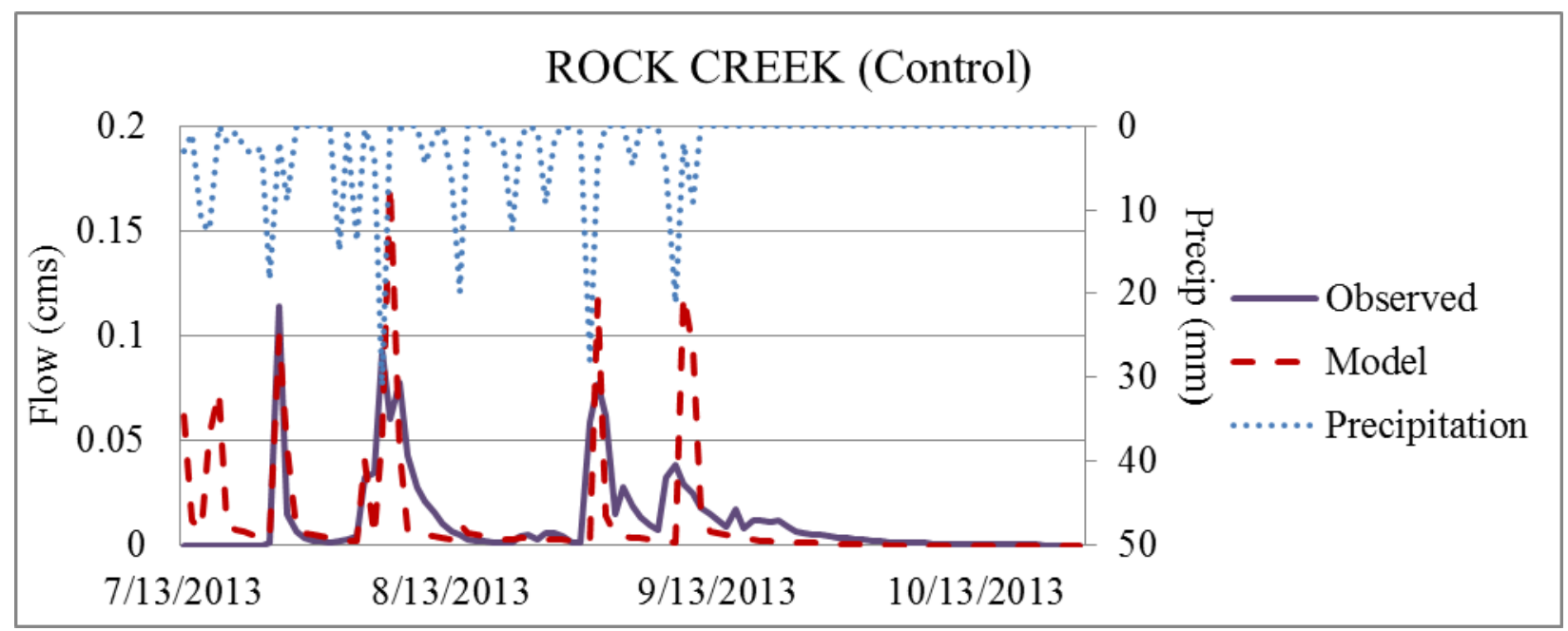

Figure 4. Hyeto-hydrograph portraying average precipitation $(\mathrm{mm})$ with observed vs. model-simulated discharge (cms) at the Rock Creek (Control) site.

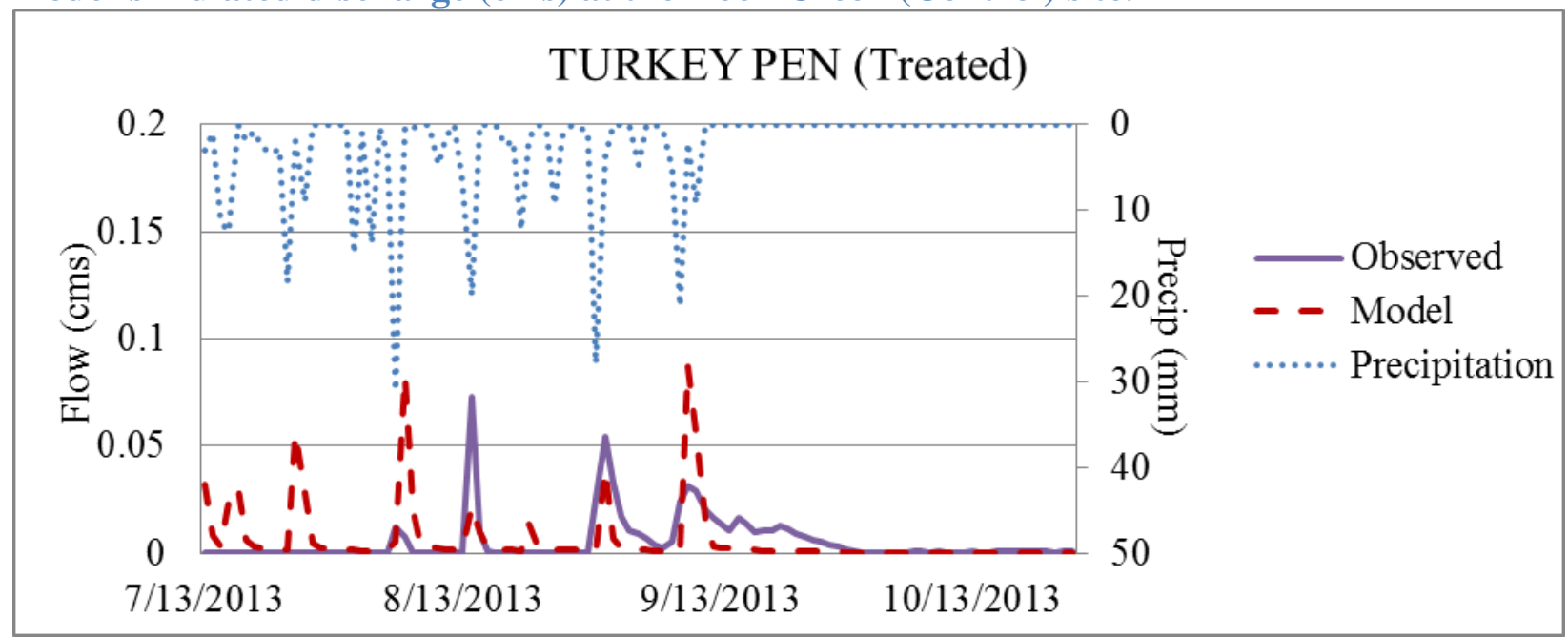

Figure 5. Hyeto-hydrograph portraying average precipitation ( $\mathrm{mm})$ with observed vs. model-simulated discharge (cms) at the Turkey Pen (Treated) site.

In order to examine the average tendency of the simulated data to deviate from the observed, we applied a percent bias (PBIAS) calculation (Eq. 6; Gupta et al. 1999): 


\section{Equation 5. PBIAS = ((Average of Observed - Average of Simulated $) * 100) /($ Average of} Observed)

where error in average flows at Rock Creek is calculated as $+/-2.34 \%$ and in Turkey Pen is $\sim+/-$ $119.76 \%$. Low-magnitude values at Rock Creek indicate accurate model simulation in the model for the study area if there are no dams. The large negative value at Turkey Pen demonstrates huge overestimation bias because the treatment (check dams) is not included in the model, thus demonstrating the effect they have on hydrology. Other metrics to report include $\mathrm{R}^{2}$ and NashSuttcliffe Efficiency (NSE), but these were developed to examine error on a monthly time step (Moriasi et al. 2007), and would not reflect the accuracy of our calibrated model in mimicking the daily peaks/volumes documented on the hydrograph. Volume might decrease at the beginning of the monsoon in the treated watershed but will increase over time, based on the observed dataset and associated analysis using PBIAS.

To better analyze how the hydrographs become desynchronized through time, we separated them into the 3 main precipitation events (storms) captured in 2013 and compared their associated runoff with the model's estimates (Fig. 6). In the first storm event (and at the beginning of the hyeto-hydrograph; Fig. 5), the model is over-estimating runoff in Turkey Pen (treated) with little difference in Rock Creek (the control). This is because the initial demands are greater in Turkey Pen when first flows are captured. Over time (during the next two precipitation events), the model starts to under-estimate runoff at Turkey Pen in comparison with Rock Creek. The model was not calibrated to take into account the extended steady flow from storage in the check dams or the increased volume realized over time in the treated watershed.

\section{Difference from Model to Observed Flow}

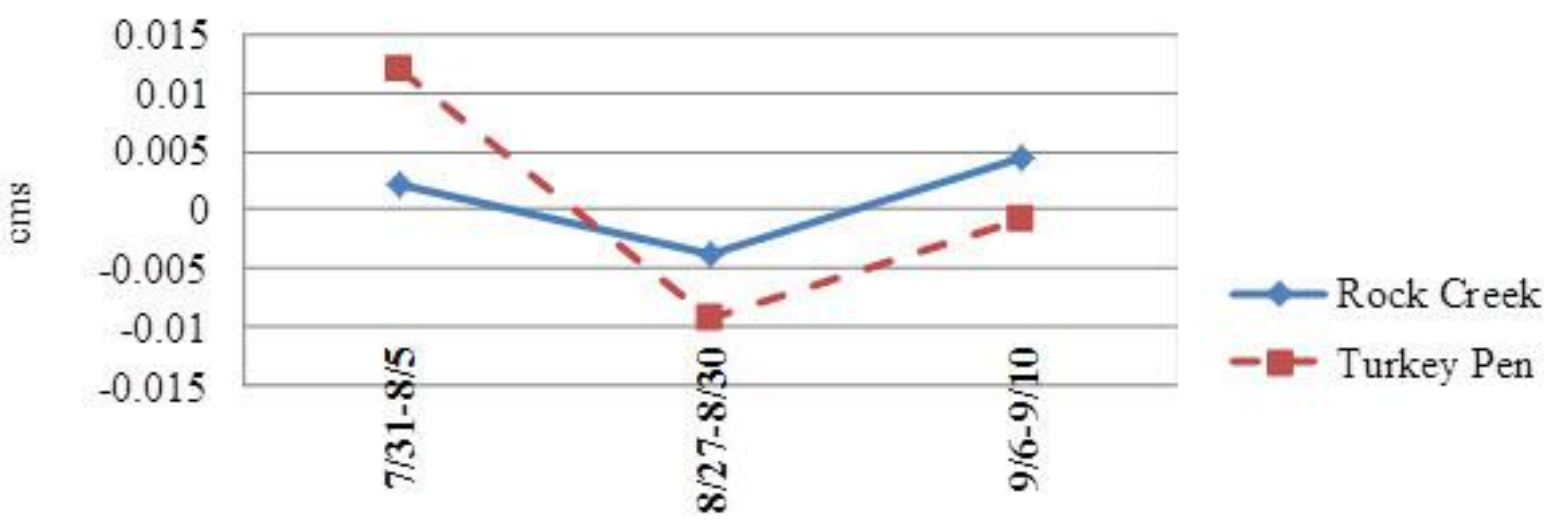

Figure 6. Graph of 3 largest precipitation events captured to compare the difference in output from observed to modeled runoff in the Treated vs. Control watersheds.

The model was run using the available measured precipitation data starting 8/26/11, for 3 years to simulate annual water and sediment budgets. Results demonstrate comparatively low surface runoff, total water yield, surface-runoff/total flow ratio (0.08), and groundwater ratio (0.28). Average annual basin stress days include water stress days (63) and temperature stress days (50) due to the aridlands climate. We assume that the differences identified in Fig. 6 radically alter the treated watershed's budget, where runoff volume increases $(28 \%)$ over time via lateral and 
baseflow, supported by soil-water storage, the increased residence time of water on the landscape also increases recharge to the aquifer downstream.

Our efforts to mimic sediment yield using the MUSLE did not provide results, but fortunately, SWAT also calculates the USLE equation which is completely dependent on precipitation (mm). The average soil loss calculated using the USLE per HRU 8.9 tons/ha (Max = 147.9; $\mathrm{MIN}=$ $0.02)$ during the time step calculated (8/26/11 - 9/30/14). We summed the estimates of soil loss and water yield to better examine cycles through time (Fig. 7). All soil loss occurs in $2 \%$ $(1.75 \%)$ of the timeframe; out of 1146 days, only 20 days have precipitation that results in eroded soil. The precipitation threshold needed to generate soil loss is $\sim 15 \mathrm{~mm} /$ day.

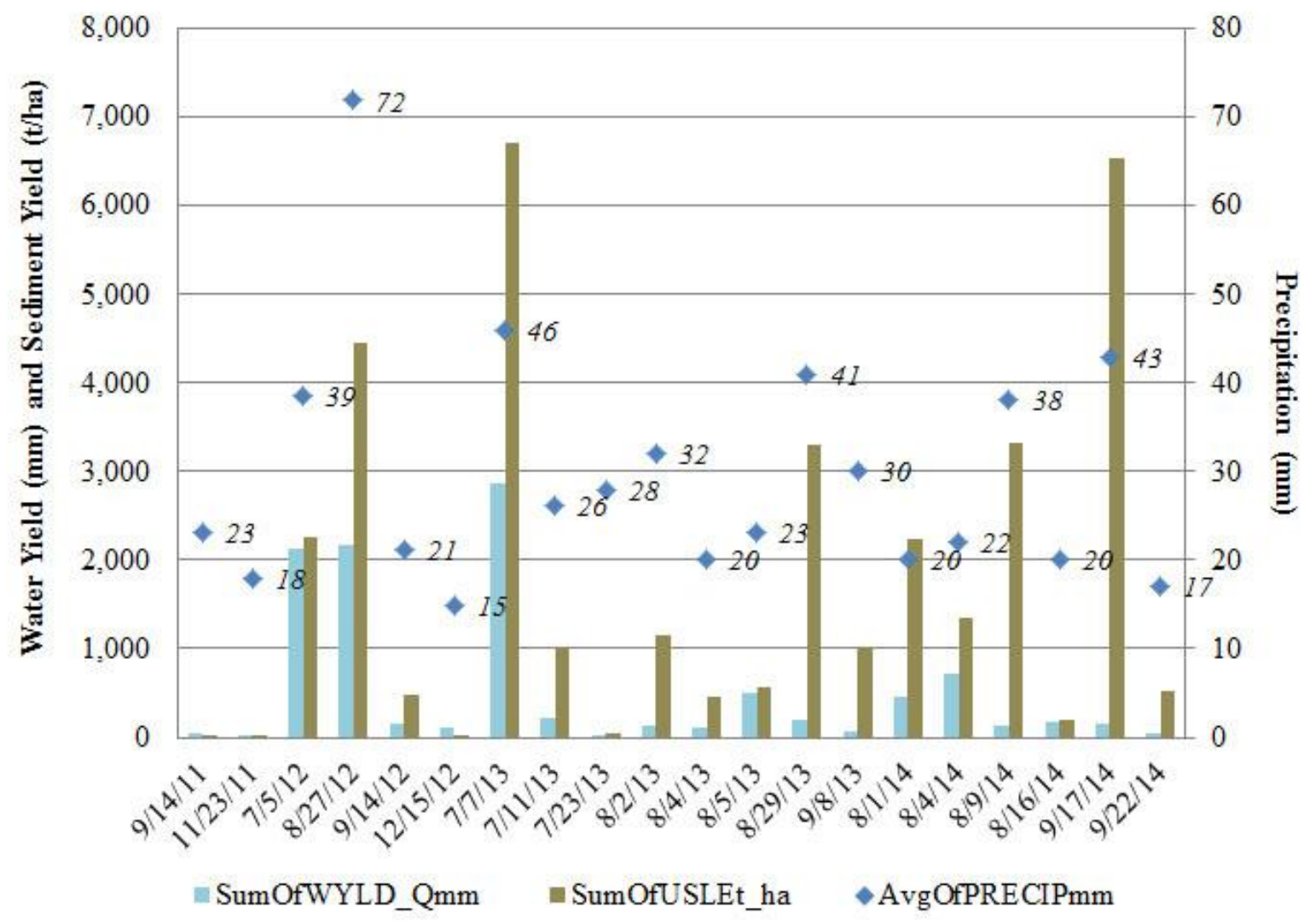

Figure 7. Graph portraying precipitation events that result in model-predicted soil erosion in the WTC paired watershed, with associated water yields.

The soil loss per HRU was summed and averaged per subbasin to create estimated sediment budgets for each subwatershed (Figure 8), where an average of 792 tons/year of soil loss is predicted at Turkey Pen during the model iteration vs. $~ 3774$ tons/year at Rock Creek. 


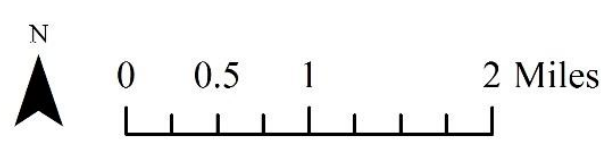

$\begin{array}{llll}0 & 0.5 & 1 & 2 \text { Kilometers }\end{array}$

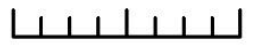

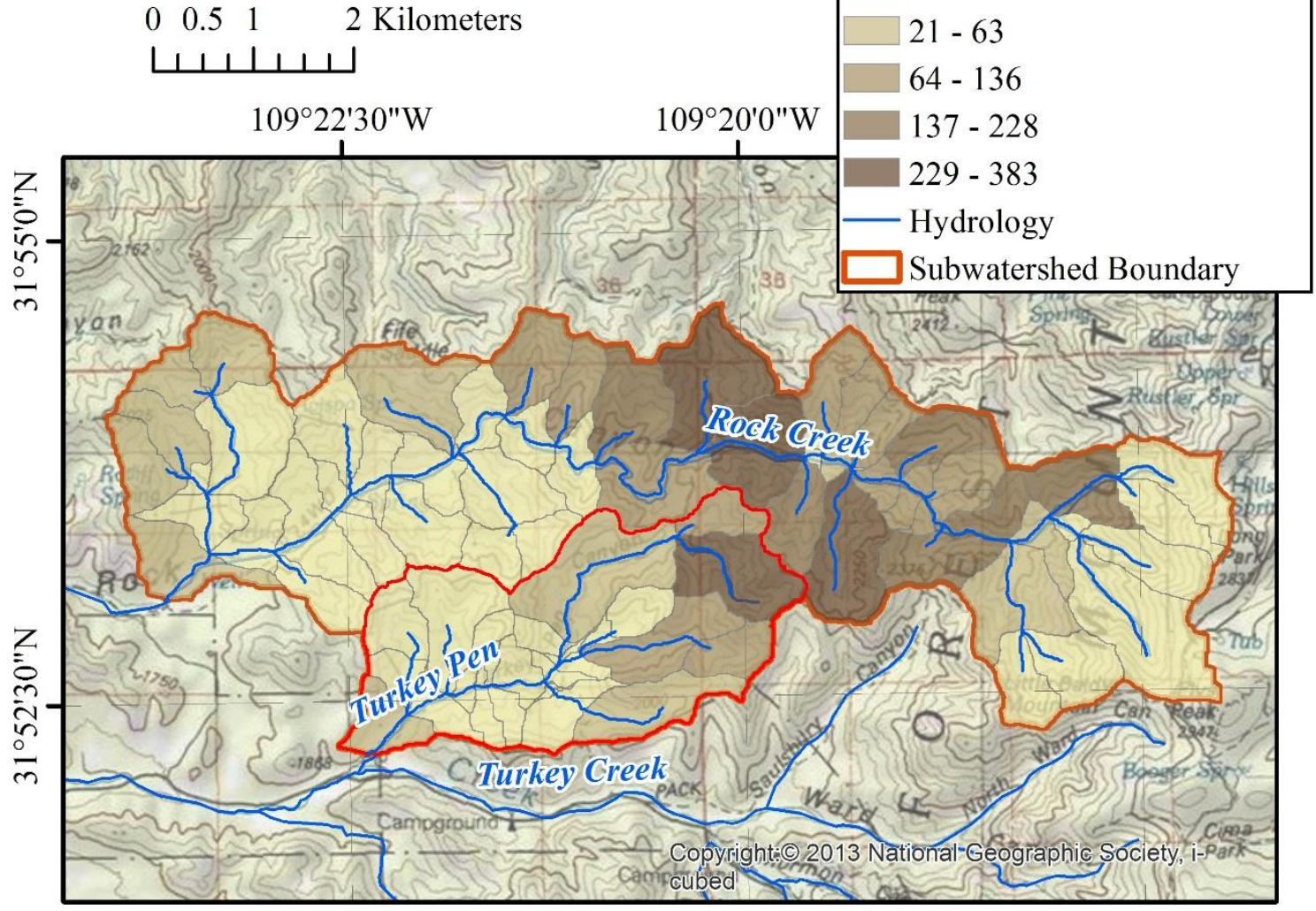

Figure 8. Map depicting the estimated average soil loss (tons/year) per subbasin per subwatershed, predicted over the three-year simulation.

Using the equation developed by Vanoni (1975; Eq. 4), a simple estimate for a SDR was calculated for the Turkey Pen watershed, where $\mathrm{SDR}=0.61$. Using the equation developed by the USDA-SCS (1979), another estimate of SDR was calculated, where SDR $=0.45$. We multiplied the average soil loss by each estimated SDR, to make a crude estimate of sediment yield. Approximately 356-483 tons of sediment would likely be yielded from the Turkey Pen (Treated) watershed, given no management considerations (i.e. if there were no check dams) and approximately1428-1936 tons are being yielded at the Control (Rock Creek).

Hadley and McQueen (1961) showed that structures in Wyoming reduced sediment loads by up to $75 \%$ and Boix-Fayos et al. (2008) calculated $77 \%$ retention at check dams in the Rogativa catchment, Murcia, Spain. Yang et al. (2009) and Xu et al. (2013) saw similar results using the SWAT model. Yang et al. (2009) found a reduction of water yield (summer) of $~ 20 \%$ and sediment yield $\sim 56 \%$, in the Black Brook Watershed, New Brunswick, Canada. Xu et al. (2013) found check dams reduced runoff in rainy season $\sim 16-30 \%$, and then increased in the dry season $\sim 20-101 \%$, and reduced sediment yield $\sim 35 \%-86 \%$ in the Yanhe watershed, China. Based on these studies and using values from Polyakov et al. (2014), who documented that check dams would retain $50 \%$ of the sediment yield over a 3-year study, we estimate the total soil retained in 
the Turkey Pen (Treated) stored by check dams throughout the watershed approximately $50 \%=$ 178-242 tons/yr (Table 2).

Table 2. Model results (assuming untreated): average discharge, soil loss, and sediment yield at the study site watershed and estimates of treatment on sediment yield.

\begin{tabular}{|c|c|c|}
\hline & Turkey Pen (Treated) & $\begin{array}{c}\text { Rock Creek } \\
\text { (Control) }\end{array}$ \\
\hline Size (ha) & 769 & 2405 \\
\hline Avg. Flow (cms) & 0.077 & 0.192 \\
\hline Average Soil Loss (USLE; Tons/Year) & 792 & 3174 \\
\hline $\begin{array}{r}\text { Avg. Sediment Yield (SDR }=0.45-0.61 ; \\
\text { Tons } / \text { Year })\end{array}$ & $356-483$ & $1428-1936$ \\
\hline $\begin{array}{r}\text { Avg. Sediment Yield IF Check Dams } \\
\text { (ton/year) }\end{array}$ & $178-242$ & $714-968$ \\
\hline
\end{tabular}

\subsection{Conclusions}

This research explored the impacts of land-use management and restoration using check dams on fluvial-sediment load and water quality. Field data collected over a three-month period was used to calibrate and train a watershed model to simulate 3 years' worth of hydrologic and sediment cycles. Obstacles we encountered were both intrinsic to the model and unavailability of input. Modelling is much faster and less expensive than implementing long-term data collection but allows for more error. Our hydrologic calibration is based on only one monsoon season and used to develop sediment transport estimates. Higher-resolution input data (DEM and soils input) would decrease error, along with more field measurements for calibration and validation of the model, including water quality (suspended sediment) and the expansion of flow. Soils data from the NRCS are not developed at high resolutions for land owned and managed by the USFS. However, the USFS does create their own very-detailed Terrestrial Ecosystem Survey that ultimately could be translated into NRCS-style geospatial datasets and greatly benefit national watershed modeling. The lateral flow component of the SWAT model that defaults to portray sub-surface flow is not appropriate in aridlands and needed to be altered to better reflect dry antecedent moisture conditions. This created errors in the model's ability to calculate sediment yield, due to the dependency of the model on lateral flow that simulates runoff and instigates erosion. While we have no measurements of sediment yield for comparison, anecdotal and pictorial evidence portrays sedimentation in the watershed and data provided within the model outputs gave estimates of soil loss - useful to approximate sediment yield and sediment retention.

The calibrated model simulated discharge with only a $2 \%$ error for the Control watershed. More than 2000 check dams installed in the Treated watershed created a huge error in the model, as expected. Those errors depict the influence that check dams have in the real world. There is a measured reduction in peak flow and a decline in volume at the beginning of the monsoon compared to the model estimates in the Treated watershed. This is followed by a relative increase in volume and duration of flow subsequent to the monsoon. The desynchronized hydrographs produced by the model portray this effect. At the beginning of the monsoon, the model overestimates runoff at Turkey Pen (Treated) due to the initial demands of created by check dams. 
Toward the end of the summer monsoon, the model starts to under-estimate flows at Turkey Pen, as it was not calibrated to take into account the soil-water storage in the check dams nor the increased and extended baseflow realized over time.

The simulation predicted erosion and soil loss on 20 days of the 3-year simulation, dependent on minimum precipitation of $15 \mathrm{~mm} /$ day. Based on the soil loss estimates, sediment yield from the study area is estimated to be $\sim 356-483$ tons/yr from the Turkey Pen (Treated) watershed (if there were no check dams) and 1428-1936 tons/yr at the Rock Creek (Control). Check dams could retain 178-242 tons/yr in the Turkey Pen (Treated) watershed over the 3-year simulation. A detailed survey of the amounts, locations and characteristics of the soils behind dams, stratigraphy of the layers and even dating of materials would be useful for better understanding of soil-water storage but could be a difficult given the nature and timing of the installation. New research to document the forest and terrestrial carbon storage associated with restoration using gabions/check dams is also warranted. The restoration being done is creating organic carbon storage in the soils, currently undocumented, but useful for restoration managers and those interested in carbon storage (ecosystem service value increases). Model simulations could ultimately be used to evaluate sediment and organic material retention, which is very important for aquatic ecosystem management and carbon sequestration, but rarely documented in the literature. The velocity and volume of water flow are important factors impacted by the installation of check dams that alter total suspended solids (TSS) or sediments in the water. High concentrations of TSS cause water quality impairment and create problems for aquatic life. Based on the discharge and sediment yield estimates developed herein, we estimate that Turkey Pen (Treated) averages $\sim 86 \mathrm{mg} / \mathrm{L}$ vs. the Rock Creek (Control) site is estimated to have $\sim 278 \mathrm{mg} / \mathrm{L}$.

In considering the dependency of the Willcox basin on nearby mountain-front recharge, it's important to note the over-withdrawals in the watershed and the inability to balance recharge currently - maybe by increasing residence time and baseflow using check dams in the entire West Turkey Creek watershed, management could help increase recharge (water quantity) and reduce impaired water quality. There is a need to better understand the long-term potential and future impacts of sediment storage related to fire, drought and biodiversity. Biodiversity is the measure of the variety of organisms present and can be impacted by changes in ecosystem variation. The resulting watershed model demonstrates a predictive framework to analyze longterm impacts of restoration and also to display potential impacts of future restoration. For example, the Control watershed (Rock Creek) could be fitted with check dams improve water quality and quantity in the future. Subbasins predicted to generate higher soil loss are mapped and could be targeted as hot spots for erosion control in future BMP's.

\section{References}

Almendinger, J. E., Murphy, M. S., \& Ulrich, J. S. (2014). Use of the Soil and Water Assessment Tool to Scale Sediment Delivery from Field to Watershed in an Agricultural Landscape with Topographic Depressions. Journal of Environment Quality, 43(1), 9. http://doi.org/10.2134/jeq2011.0340

Arizona Department of Water Resources. (2009). Section 3.14 Willcox Basin. In Arizona Water Atlas (Vol. 3, pp. 534-602). Retrieved from 
http://www.azwater.gov/AzDWR/StatewidePlanning/wateratlas/SEArizona/documents/Volume_ 3_WIL_final.pdf

Arnold, J. G., Allen, P. M., \& Morgan, D. S. (2001). Hydrologic model for design and constructed. Wetlands, 21(2), 167-178. http://doi.org/10.1672/0277-

5212(2001)021[0167:HMFDAC]2.0.CO;2

Arnold, J. G., Srinivasan, R., Muttiah, R. S., \& Williams, J. R. (1998). Large Area Hydrologic Modeling and Assessment Part I: Model Development1. JAWRA Journal of the American Water Resources Association, 34(1), 73-89. http://doi.org/10.1111/j.1752-1688.1998.tb05961.x

Baker Jr., M. B., DeBano, L. F., \& Ffolliott, P. F. (1995). Hydrology and watershed management in the Madrean Archipelago. In DeBano, L.H.; Ffolliott, P.H.; Ortega-Rubio, A.; Gottfried, G.J.; Hamre, R.H.; Edminster, C.B., tech. coords. Biodiversity and management of the madrean archipelago: the sky islands of southwestern United States and northwestern Mexico. 1994 Sept. 19-23; Tucson, AZ (pp. 329-337). Fort Collins, CO: U.S. Department of Agriculture, Forest Service, Rocky Mountain Forest and Range Experiment Station.

Boix-Fayos, C., de Vente, J., Martínez-Mena, M., Barberá, G. G., \& Castillo, V. (2008). The impact of land use change and check-dams on catchment sediment yield. Hydrological Processes, 22(25), 4922-4935. http://doi.org/10.1002/hyp.7115

Bombino, G., Gurnell, A. M., Tamburino, V., Zema, D. A., \& Zimbone, S. M. (2009). Adjustments in channel form, sediment calibre and vegetation around check-dams in the headwater reaches of mountain torrents, Calabria, Italy. Earth Surface Processes and Landforms, 34(7), 1011-1021. http://doi.org/10.1002/esp.1791

Bonumá, N. B., Rossi, C. G., Arnold, J. G., Reichert, J. M., Minella, J. P., Allen, P. M., \& Volk, M. (2014). Simulating Landscape Sediment Transport Capacity by Using a Modified SWAT Model. Journal of Environment Quality, 43(1), 55. http://doi.org/10.2134/jeq2012.0217

Box, G. E. P. (1987). Empirical Model-Building and Response Surfaces (1 edition). New York: Wiley.

Brady, L. M., Gray, F., Wissler, C., \& Guertin, D. P. (2001). Spatial variability of sediment erosion processes using GIS analysis within watersheds in a historically mined region, Patagonia Mountains, Arizona. U.S. Geological Survey Open-File Report, 01-267. Retrieved from http://geopubs.wr.usgs.gov/open-file/of01-267/

Branson, F. A., Gifford, G. F., Renard, K. B., \& Hadley, R. F. (1981). Rangeland Hydrology, Soc. Rng. Mgmt., Rng. Sci. Ser, 1.

Brown, S. G., \& Schumann, H. H. (1969). Geohydrology and Water Utilization in the Willcox Basin, Graham and Cochise Counties Arizona (U.S. Geological Survey Water-Supply Paper No. 1859F). Retrieved from http://pubs.usgs.gov/wsp/1859f/report.pdf

Chaubey, I., Migliaccio, K. W., Green, C. H., Arnold, J. G., \& Srinivasan, R. (2006). Phosphorus modeling in soil and water assessment tool (SWAT) model. In Modeling phosphorus in the environment (pp. 163-188). Boca Raton, FL: CRC Press.

Coblentz, D. (2005). The Tectonic Evolution of the Madrean Archipelago and Its Impact on the Geoecology of the Sky Islands. In Gottfried, Gerald J.; Gebow, Brooke S.; Eskew, Lane G.; and Edminster, Carleton B., compilers. 2005. Connecting mountain islands and desert seas: biodiversity and management of the Madrean Archipelago II. 2004 May 11-15; Tucson, AZ. (pp. 62-68). Fort Collins, CO: U.S. Department of Agriculture, Forest Service, Rocky Mountain Research Station. Retrieved from http://www.fs.fed.us/rm/pubs/rmrs_p036/rmrs_p036_062_068.pdf 
De Vente, J., \& Poesen, J. (2005). Predicting soil erosion and sediment yield at the basin scale: Scale issues and semi-quantitative models. Earth-Science Reviews, 71(1-2), 95-125. http://doi.org/10.1016/j.earscirev.2005.02.002

DeBano, L. F., \& Heede, B. H. (1987). Enhancement of Riparian Ecosystems with Channel Structures1. JAWRA Journal of the American Water Resources Association, 23(3), 463-470. http://doi.org/10.1111/j.1752-1688.1987.tb00824.x

Debano, L. F., \& Schmidt, L. J. (1990). Potential for enhancing riparian habitats in the southwestern United States with watershed practices. Forest Ecology and Management, 33-34, 385-403. http://doi.org/10.1016/0378-1127(90)90205-P

Du, B., Arnold, J. G., Saleh, A., \& Jaynes, D. B. (2005). DEVELOPMENT AND APPLICATION OF SWAT TO LANDSCAPES WITH TILES AND POTHOLES. Transactions of the ASAE, 48(3), 1121-1133. http://doi.org/10.13031/2013.18522

Fuller, J. (2015). Cochise County ALERT system. Retrieved from http://jefullerdata.com/Cochise/index 1h.html

Garbrecht, J. D., Nearing, M. A., Shields, F. D., Tomer, M. D., Sadler, E. J., Bonta, J. V., \& Baffaut, C. (2014). Impact of weather and climate scenarios on conservation assessment outcomes. Journal of Soil and Water Conservation, 69(5), 374-392. http://doi.org/10.2489/jswc.69.5.374

Gassman, P. W., Reyes, S. H., Green, C. H., \& Arnold, J. G. (2007). The Soil and Water Assessment Tool: Historical development, applications, and future research directions (Vol. 50(4), p. 1211-1250). Presented at the Trans. ASABE.

Goodrich, D. C., Keefer, T. O., Unkrich, C. L., Nichols, M. H., Osborn, H. B., Stone, J. J., \& Smith, J. R. (2008). Long-term precipitation database, Walnut Gulch Experimental Watershed, Arizona, United States. Water Resources Research, 44(5), W05S04. http://doi.org/10.1029/2006WR005782

Gray, J. R., Glysson, G. D., Turcios, L. M., \& Schwarz, G. E. (2000). Comparability of suspendedsediment concentration and total suspended solids data (Water-Resources Investigations Report No. 00-4191). USGS.

Griffiths, P. G., Hereford, R., \& Webb, R. H. (2006). Sediment yield and runoff frequency of small drainage basins in the Mojave Desert, U.S.A. Geomorphology, 74(1-4), 232-244. http://doi.org/10.1016/j.geomorph.2005.07.017

Griffiths, W. H., \& Walton, B. (1978). The effects of sedimentation on the aquatic biota (Alberta Oil Sands Environmental Research Program No. 35) (p. 86).

Gupta, H. V., Sorooshian, S., \& Yapo, P. O. (1999). Status of automatic calibration for hydrologic models: Comparison with multilevel expert calibration. J. Hydrologic Eng. 4(2): 135-143

Hadley, R. F., \& McQueen, I. S. (1961). Hydrologic effects of water spreading in Box Creek basin, Wyoming (No. WSP - 1532-A). United States Geological Survey. Retrieved from http://pubs.er.usgs.gov/publication/wsp1532A

Hassanli, A. M., Nameghi, A. E., \& Beecham, S. (2008). Evaluation of the effect of porous check dam location on fine sediment retention (a case study). Environmental Monitoring and Assessment, 152(1-4), 319-326. http://doi.org/10.1007/s10661-008-0318-2

Heede, B. H. (1978). Designing gully control systems for eroding watersheds. Environmental Management, 2(6), 509-522. http://doi.org/10.1007/BF01866709

Heede, B. H., \& DeBano, L. F. (1984). Gully rehabilitation-a three-stage process in a sodic soil. Soil Science Society of America Journal, 48(6), 1416-1422. 
Hendrickson, D. A., \& Minckley, W. L. (1985). Cienegas: vanishing climax communities of the American Southwest. Desert Plants (USA). Retrieved from http://agris.fao.org/agrissearch/search.do?f=1986/US/US86099.xml;US8603277

Jacobson, J., Davis, T., Hinckley, A., Schmerge, D., \& Flora, S. (2008). WATER LEVEL CHANGES IN WILLCOX BASIN, ARIZONA 1999-2005 (WATER LEVEL CHANGE MAP SERIES No. REPORT NO. 1). Arizona Dept of Water Resources.

Kingsford, R. t. (2000). Ecological impacts of dams, water diversions and river management on floodplain wetlands in Australia. Austral Ecology, 25(2), 109-127. http://doi.org/10.1046/j.14429993.2000.01036.x

Kiesel, J., Fohrer, N., Schmalz, B., \& White, M. J. (2010). Incorporating landscape depressions and tile drainages of a northern German lowland catchment into a semi-distributed model. Hydrological Processes, 24(11), 1472-1486. http://doi.org/10.1002/hyp.7607

Lane, L. J., Hernandez, M., \& Nichols, M. (1997). Processes controlling sediment yield from watersheds as functions of spatial scale. Environmental Modelling \& Software, 12(4), 355-369. http://doi.org/16/S1364-8152(97)00027-3

Liu, Y., Yang, W., \& Wang, X. (2008). Development of a SWAT extension module to simulate riparian wetland hydrologic processes at a watershed scale. Hydrological Processes, 22(16), 2901-2915. http://doi.org/10.1002/hyp.6874

Lopes, V. L., \& Ffolliott, P. F. (1992). Hydrology and watershed management of oak woodlands in southwestern Arizona. In Ecology and management of oak and associated woodlands : perspectives in the southwestern United States and northern Mexico (p. 224). Fort Collins, CO: Rocky Mountain Forest and Range Experiment Station. Retrieved from http://www.alibris.com/Ecology-and-management-of-oak-and-associated-woodlandsperspectives-in-the-southwestern-United-States-and-northern-Mexico-April-27-30-1992-SierraVista-Arizona-Peter-F-Ffolliott/book/1877526

Marsh, J. A. (1968). The effect of suspended sediment and discharge on naturTal infiltration of ephemeral streams (M.S.). University of Arizona, Tucson, Ariz. Retrieved from http://arizona.openrepository.com/arizona/bitstream/10150/191501/1/azu_td_hy_e9791_1968_24 5_sip1_w.pdf

Martín-Rosales, W., Gisbert, J., Pulido-Bosch, A., Vallejos, A., \& Fernández-Cortés, A. (2007). Estimating groundwater recharge induced by engineering systems in a semiarid area (southeastern Spain). Environmental Geology, 52(5), 985-995. http://doi.org/10.1007/s00254006-0541-5

Mishra, A., Fröbrich, J., \& Kar, S. (2003). POTENTIALS AND APPLICABILITY OF THE SWAT MODEL IN CHECK DAM MANAGEMENT IN SMALL WATERSHED. Retrieved from http://swat.tamu.edu/docs/swat/conferences/2003/Session\%20D/Ashok.pdf

Mishra, A., Froebrich, J., \& Gassman, P. (2007). Evaluation of the SWAT model for assessing sediment control structures in a small watershed in India. American Society of Agricultural and Biological Engineers, 50(2), 469-477.

Moriasi, D. N., Arnold, J. G., Van Liew, M. W., Bingner, R. L., Harmel, R. D., \& Veith, T. L. (2007). Model Evaluation Guidelines for Systematic Quantification of Accuracy in Watershed Simulations. Transactions of the ASABE, 50(3), 885-900. http://doi.org/10.13031/2013.23153

Mwangi, J. K., Shisanya, C. A., Gathenya, J. M., Namirembe, S., \& Moriasi, D. N. (2015). A modeling approach to evaluate the impact of conservation practices on water and sediment yield in Sasumua Watershed, Kenya. Journal of Soil and Water Conservation, 70(2), 75-90. http://doi.org/10.2489/jswc.70.2.75 
Nearing, M. A., Nichols, M. H., Stone, J. J., Renard, K. G., \& Simanton, J. R. (2007). Sediment yields from unit-source semiarid watersheds at Walnut Gulch. Water Resources Research, 43(6), W06426. http://doi.org/10.1029/2006WR005692

Neitsch, S. L., Arnold, J. G., Kiniry, J. R., \& Williams, J. R. (2009). Soil and Water Assessment Tool: Theoretical Documentation. Retrieved from http://www. brc.tamus.edu/swat/

Nichols, M. H. (2006). Measured Sediment Yield Rates From Semiarid Rangeland Watersheds. Rangeland Ecology \& Management, 59(1), 55-62. http://doi.org/10.2111/05-075R1.1

Nichols, M. H., McReynolds, K., \& Reed, C. (2012). Short-term soil moisture response to low-tech erosion control structures in a semiarid rangeland. CATENA, 98, 104-109. http://doi.org/10.1016/j.catena.2012.06.010

Niraula, R., Meixner, T., \& Norman, L. M. (2015). Determining the importance of model calibration for forecasting absolute/relative changes in streamflow from LULC and climate changes. Journal of Hydrology, 522, 439-451. http://doi.org/10.1016/j.jhydrol.2015.01.007

Niraula, R., Kalin L., Wang, R., \& Srivastava, P. (2012b). Determining Nutrient and Sediment Critical Source Areas with SWAT Model: Effect of Lumped Calibration. Trans. of ASABE, 55 (1): 147-157.

Niraula, R., Norman, L. M., Meixner, T., \& Callegary, J. (2012a). Multi-gauge Calibration for modeling the Semi-Arid Santa Cruz Watershed in Arizona-Mexico Border Area Using SWAT. Air, Soil and Water Research, (5), 41. http://doi.org/10.4137/ASWR.S9410

Norman, L. M. (2005). Modeling land use change and associate water quality impacts in the Ambos Nogales watershed, United States-Mexico border. THE UNIVERSITY OF ARIZONA. Retrieved from http://phdtree.org/pdf/25545994-modeling-land-use-change-and-associate-waterquality-impacts-in-the-ambos-nogales-watershed-united-states-mexico-border/

Norman, L. M. (2007). United States-Mexican border watershed assessment: Modeling nonpoint source pollution in Ambos Nogales. Journal of Borderlands Studies, 22(1), 79-97. http://doi.org/10.1080/08865655.2007.9695670

Norman, L. M., Brinkerhoff, F., Gwilliam, E., Guertin, D. P., Callegary, J., Goodrich, D. C., ... Gray, F. (2015). Hydrologic Response of Streams Restored with Check Dams in the Chiricahua Mountains, Arizona. River Research and Applications, n/a-n/a. http://doi.org/10.1002/rra.2895

Norman, L. M., Gray, F., Guertin, D. P., Wissler, C., \& Bliss, J. D. (2007). Tracking acid minedrainage in Southeast Arizona using GIS and sediment delivery models. Environmental Monitoring and Assessment, 145(1-3), 145-157. http://doi.org/10.1007/s10661-007-0024-5

Norman, L. M., Huth, H., Levick, L., Shea Burns, I., Phillip Guertin, D., Lara-Valencia, F., \& Semmens, D. (2010a). Flood hazard awareness and hydrologic modelling at Ambos Nogales, United States-Mexico border. Journal of Flood Risk Management, 3(2), 151-165. http://doi.org/10.1111/j.1753-318X.2010.01066.x

Norman, L. M., Levick, L. R., Guertin, D. P., Callegary, J. B., Quintanar Guadarrama, J., Zulema Gil Anaya, C., ... Octavio Gastelum Ceballos, F. (2010b). Nogales flood detention study. U.S. Geological Survey Open-File Report, 2010-1262, 112.

Norman, L. M., Villarreal, M. L., Pulliam, H. R., Minckley, R., Gass, L., Tolle, C., \& Coe, M. (2014). Remote sensing analysis of riparian vegetation response to desert marsh restoration in the Mexican Highlands. Ecological Engineering, 70C, 241-254.

http://doi.org/10.1016/j.ecoleng.2014.05.012

Osterkamp, W. R. (1999). Runoff and Sediment Yield from Proxy Records: Upper Animas Creek Basin, New Mexico (Rocky Mountain Research Station Research Paper No. RMRS-RP-18) (p. 50). Fort Collins, CO: United States Department of Agriculture Forest Service. 
Ouessar, M., Bruggeman, A., Mohtar, R., Ouerchefani, D., Abdelli, F., \& Boufelgha, M. (2008). Future of Drylands - An Overview of Evaluation and Impact Assessment Tools for Water Harvesting. In C. Lee \& T. Schaaf (Eds.), The Future of Drylands (pp. 255-267). Springer Netherlands. Retrieved from http://link.springer.com/chapter/10.1007/978-1-4020-6970-3_29

Peterson, H. V., DeJulio, O. P., \& Rupkey, R. H. (1960). Effect of Bureau of Land Management structures on discharge of San Simon Creek and on irrigation diversions in Safford Valley, Arizona. (U.S. Geological Survey Administrative Report) (p. 85).

Pettersson, T. (1998). Water quality improvement in a small stormwater detention pond. Water Science and Technology, 38(10), 115-122. http://doi.org/10.1016/S0273-1223(98)00740-9

Poesen, J. W. A., \& Hooke, J. M. (1997). Erosion, flooding and channel management in Mediterranean environments of southern Europe. Progress in Physical Geography, 21(2), 157199. http://doi.org/10.1177/030913339702100201

Polyakov, V. O., Nearing, M. A., Nichols, M. H., Scott, R. L., Stone, J. J., \& McClaran, M. P. (2010). Long-term runoff and sediment yields from small semiarid watersheds in southern Arizona. Water Resources Research, 46(9), W09512. http://doi.org/10.1029/2009WR009001

Polyakov, V. O., Nichols, M. H., McClaran, M. P., \& Nearing, M. A. (2014). Effect of check dams on runoff, sediment yield, and retention on small semiarid watersheds. Journal of Soil and Water Conservation, 69(5), 414-421. http://doi.org/10.2489/jswc.69.5.414

Remaître, A., van Asch, T. W. J., Malet, J.-P., \& Maquaire, O. (2008). Influence of check dams on debris-flow run-out intensity. Natural Hazards and Earth System Science, 8(6), 1403-1416. http://doi.org/10.5194/nhess-8-1403-2008

Rockström, J., Karlberg, L., Wani, S. P., Barron, J., Hatibu, N., Oweis, T., Bruggeman, A., Farahani, J., Qiang, Z. (2010). Managing water in rainfed agriculture-The need for a paradigm shift. Agricultural Water Management, 97(4), 543-550. http://doi.org/10.1016/j.agwat.2009.09.009

Schreiber, H. A., \& Kincaid, D. R. (1967). Regression models for predicting on-site runoff from short-duration connective storms. Water Resources Research, 3(2), 389-395. http://doi.org/10.1029/WR003i002p00389

Tesfahunegn, G. B., Vlek, P. L., \& Tamene, L. (2013). Application of SWAT model to assess erosion hotspot for sub-catchment management at Mai-Negus catchment in northern Ethiopia. East African Journal of Science and Technology, 2(2), 97-123.

USDA Soil Conservation Service (USDA-SCS 1975). Sediment Sources, Yields, and Delivery Ratios. National Engineering Handbook, Section 3 Sedimentation.

US Geological Survey (2015). USGS Water-Data Site Information for the Nation. Retrieved from http://waterdata.usgs.gov/nwis/si

Vanoni, V. A. (1975). Sedimentation engineering (No. Manual and Report No. 54.). New York, N.Y.: American Society of Civil Engineers. Retrieved from http://cedb.asce.org/cgi/WWWdisplay.cgi?139314

Waidler, D., White, M., Steglich, E., Wang, S., Williams, J., Jones, C. A., \& Srinivasan, R. (2011). Conservation practice modeling guide for SWAT and APEX. Texas Water Resources Institute Technical Report, (399), 71.

Wang, L., \& Yu, J. (2012). Modelling detention basins measured from high-resolution light detection and ranging data: MODELLING DETENTION BASINS FROM HIGH-RESOLUTION LIDAR DATA. Hydrological Processes, 26(19), 2973-2984. http://doi.org/10.1002/hyp.8314

Wang, X., Shang, S., Qu, Z., Liu, T., Melesse, A. M., \& Yang, W. (2010). Simulated wetland conservation-restoration effects on water quantity and quality at watershed scale. Journal of Environmental Management, 91(7), 1511-1525. http://doi.org/10.1016/j.jenvman.2010.02.023 
Wang, X., Yang, W., \& Melesse, A. M. (2008). Using hydrologic equivalent wetland concept within SWAT to estimate streamflow in watersheds with numerous wetlands. In 55-72 (Vol. vol.51, no.1, pp. 55-72).

White, M. J. (2001). Evaluation of management practices and examination of spatial detail effects using the swat model. Oklahoma State University. Retrieved from https://afrsweb.usda.gov/sp2UserFiles/ad_hoc/62060505MikeWhite/pdfs/white_thesis.pdf

White, M. J., Storm, D. E., Busteed, P., Stoodley, S., \& Phillips, S. J. (2010). Evaluating Conservation Program Success with Landsat and SWAT. Environmental Management, 45(5), 1164-1174. http://doi.org/10.1007/s00267-010-9458-6

Wickham, J., Homer, C., Vogelmann, J., McKerrow, A., Mueller, R., Herold, N., \& Coulston, J. (2014). The Multi-Resolution Land Characteristics (MRLC) Consortium-20 years of development and integration of USA national land cover data. Remote Sensing, 6(8), 7424-7441.

Williams, J. R. (1975). Sediment-yield prediction with universal equation using runoff energy factor. In Proceedings of the Sediment-Yield Workshop (Vol. Publ. ARS-S-40, pp. 244-252). Oxford, MS.: USDA Sedimentation Laboratory.

Williams, J. R. (1977). Sediment delivery ratios determined with sediment and runoff models. Erosion and Solid Matter Transport in Inland Waters, IAHS-AISH publication(No. 122), 168179.

Winchell, M., Srinivasan, R., Di Luzio, M., \& Arnold, J. (2009). ARCSWAT 2.3. 4 interface for SWAT2005: User's guide. Temple, Texas: Blackland Research Center, Texas Agricultural Experiment Station. Wischmeier, W. H., \& Smith, D. D. (1978). Predicting Rainfall-Erosion Losses A Guide to Conservation Plannings (Agriculture Handbook No. No. 537). Washington: USDA. Retrieved from http://topsoil.nserl.purdue.edu/usle/AH_537.pdf

$\mathrm{Xu}$, Y. D., Fu, B. J., \& He, C. S. (2013). Assessing the hydrological effect of the check dams in the Loess Plateau, China, by model simulations. Hydrol. Earth Syst. Sci., 17(6), 2185-2193. http://doi.org/10.5194/hess-17-2185-2013

Yang, Q., Meng, F.-R., Zhao, Z., Chow, T. L., Benoy, G., Rees, H. W., \& Bourque, C. P.-A. (2009). Assessing the impacts of flow diversion terraces on stream water and sediment yields at a watershed level using SWAT model. Agriculture, Ecosystems \& Environment, 132(1-2), 23-31. http://doi.org/10.1016/j.agee.2009.02.012

Young, K. D., Younos, T., Dymond, R. L., Kibler, D. F., \& Lee, D. H. (2010). Application of the Analytic Hierarchy Process for Selecting and Modeling Stormwater Best Management Practices. Journal of Contemporary Water Research \& Education, 146(1), 50-63. http://doi.org/10.1111/j.1936-704X.2010.00391.x

Zabaleta, A., Martínez, M., Uriarte, J. A., \& Antigüedad, I. (2007). Factors controlling suspended sediment yield during runoff events in small headwater catchments of the Basque Country. CATENA, 71(1), 179-190. http://doi.org/10.1016/j.catena.2006.06.007 